Int. J. Morphol.,

33(2):465-470, 2015.

\title{
Immunohistochemical Overexpression of MAP-2 in the Cerebral Cortex of Rabies-Infected Mice
}

\author{
Aumento en la Expresión Inmunohistoquímica de MAP-2 \\ en la Corteza Cerebral de Ratones Infectados con Rabia
}

Andrea P. Hurtado*; Aura Caterine Rengifo* \& Orlando Torres-Fernández*

HURTADO, A. P.; RENGIFO, A. C. \& TORRES-FERNÁNDEZ, O. Immunohistochemical overexpression of MAP-2 in the cerebral cortex of rabies-infected mice. Int. J. Morphol., 33(2):465-470, 2015.

SUMMARY: The microtubule-associated protein MAP-2 is an integral part of the cytoskeleton and plays an important role in neural morphogenesis. This protein is an essential component of the dendritic cytoskeleton, especially in the adult brain, and its expression can be altered under experimental or pathological conditions. The purpose of this study was to evaluate the effect of infection with the rabies virus on MAP-2 immunoreactivity in the cerebral cortex of mice. The mice were inoculated with the rabies virus and the animals were sacrificed when the disease reached its advanced stage, together with uninfected animals of the same age. The brains were extracted after being previously perfusion-fixed with paraformaldehyde; coronal sections were obtained with a vibratome. The coronal sections were processed by immunohistochemistry to reveal the presence of the MAP-2 protein in neurons of the motor area of the cerebral cortex. Rabies-infected mice showed an increase in the immunoreactivity of the somata and apical dendrites in pyramidal neurons of the motor cortex. This is an unexpected result, as dendritic pathology has been previously demonstrated in rabies, and some studies on neurological disorders associate dendritic alterations with loss of expression of the MAP-2 protein. Therefore, whatever the alteration in the expression of this protein, decrease or increase, it could be causing a biochemical imbalance in the integrity and stability of the neuronal cytoskeleton.

KEY WORDS: MAP-2; Cerebral cortex; Pyramidal neurons; Rabies virus; Immunohistochemistry.

\section{INTRODUCTION}

Rabies is caused by a neurotropic virus, as it infects neurons almost exclusively and spreads through their extensive network of connections. Rabies is a zoonosis transmitted mainly by carnivore mammals or bats through the bite of an infected animal. When the virus comes into contact with specific cells of the muscle fibers of the infected individual, it enters through peripheral nerves, reaches the spinal cord and ascends to the brain through the motor tracts by retrograde axonal transport (Jackson \& Fu, 2013). Although rabies symptoms are very dramatic, there are, paradoxically, very few morphological changes (macroscopic and microscopic) in the nervous system (Iwasaki \& Tobita, 2002). However, a preliminary study using the Golgi technique demonstrated changes in the morphology of the pyramidal cells of the cerebral cortex of mice inoculated with the rabies virus. Among the most notable changes are the decrease in the size of the somata and of the dendritic trees, the thinning of the apical dendrites and the loss of dendritic spines (Torres-Fernández et al., 2007).
In certain neurological diseases, a relationship has been established between the dendritic pathology described using the Golgi technique and the loss of expression of the microtubule-associated protein MAP-2 (Broadbelt et al., 2002; Kaufmann et al., 2000; Montgomery et al., 1999). MAP-2 is a structural protein that confers stability to the neuronal cytoskeleton by promoting the polymerization and stabilization of microtubules by way of links between adjacent microtubules. MAP-2 is the most abundant MAP in mammalian brains; it is mainly located in the dendrites in adult brains (Johnson \& Jope, 1992; Conde \& Cáceres, 2009). A direct relationship has been established between the concentration of MAP-2 and the degree of dendritic arborization of a neuron. An example is Purkinje cells, where MAP-2 is uniformly distributed throughout the dendritic tree (Johnson \& Jope).

Based on this background, the present study was conducted in order to establish the relationships between 
the dendritic pathology previously demonstrated with the Golgi technique and the expression of the MAP-2 protein in the nervous tissue affected by rabies. A previous study reported the loss of MAP-2 in primary neurons in cultures infected with fixed rabies virus (Li et al., 2005), while another study found no qualitative difference in the immunoreactivity of MAP-2 in mice hippocampal pyramidal neurons inoculated with street rabies virus (Song et al., 2013).

\section{MATERIAL AND METHOD}

Management and inoculation of the animals with rabies virus. We used ICR female mice (Institute of Cancer Research) of approximately 28 days of age and an average weight of 21 grams. The animals were kept in the animal facility of the Instituto Nacional de Salud (INS), in a high security room. All animal-related manipulations were performed in this room until the brains were fixed in paraformaldehyde (PFA); they were then taken to the laboratory for immunohistochemistry. Our study followed ethical and legal standards for laboratory animal research and the animal handling protocol was approved by the Ethics Committee of the INS.

We worked with two types of rabies virus supplied in aliquots by the Virology Laboratory of the INS: wild virus (street virus) of canine origin and laboratory-adapted virus (fixed virus) of the universal strain CVS (Challenge Virus Standard). For the experiment with street virus, each animal was inoculated with $0.03 \mathrm{ml}$ of an aliquot diluted $10^{-1}$, equivalent to $10^{6}$ DL50. For the experiment with fixed virus, each mouse was inoculated with $0.03 \mathrm{ml}$ of an aliquot diluted $10^{-1}$ equivalent to $10^{9}$ DL50. Ten mice were inoculated with each of the two types of virus, five intracerebrally via the left parietal bone and five through the intramuscular route in the hind limbs between the semitendinosus and semimembranosus muscles. Twenty animals were inoculated simultaneously using the same distribution and procedure mentioned above but only with the vehicle solution (the diluent without the virus); these animals were used as controls.

When the animals inoculated with rabies virus reached the terminal stage of the disease (between 5 and 14 days on average, depending on the type of virus and the inoculation route), the diseased mice and their controls were anesthetized by intraperitoneally injecting chloral hydrate $30 \%$. Intracardiac perfusion was performed immediately, initially with $50 \mathrm{ml}$ of phosphate buffer saline (PBS) at $\mathrm{pH}$ 7.3 and then $100 \mathrm{ml}$ of $4 \%$ PFA. The brains were then removed, immersed in fresh solution of $4 \%$ PFA and kept at $4{ }^{\circ} \mathrm{C}$ until processing for immunohistochemical analysis.
Immunohistochemistry for MAP-2. Fifty-microns thick coronal sections of the brains, in rostro-caudal direction, were obtained with a vibratome. During the entire immunohistochemical procedure, the sections were left freefloating and in constant stirring at room temperature $\left(20^{\circ} \mathrm{C}\right)$. Initially, the sections were washed in PBS overnight. The next day they were treated for $30 \mathrm{~min}$ with ammonium chloride $\left(\mathrm{NH}_{4} \mathrm{Cl}\right)$ to quench aldehydes and then with hydrogen peroxide $\left(\mathrm{H}_{2} \mathrm{O}_{2}\right) 3 \%$ for 30 min to block endogenous peroxidase. After washing in PBS, the sections were treated with bovine serum albumin (3\%) and normal horse serum (3\%) for $30 \mathrm{~min}$ to block non-specific sites. The sections were then incubated with anti-MAP-2 primary antibody (Santa Cruz, MAP-2 (H300): sc-20172, polyclonal, vial contains $200 \mu \mathrm{g} \mathrm{IgG} \mathrm{in} 1 \mathrm{ml}$ of PBS) diluted 1:1000 for $24 \mathrm{~h}$ and then with secondary antibody (biotinylated anti-rabbit IgG Sigma 1:200) for $2 \mathrm{~h}$, followed by ABC solution (Vectastain) for $2 \mathrm{~h}$. A DAB-Nickel Kit (Vectastain) was used as chromogen. The sections were mounted on slides covered with gelatin for greater adherence, allowed to dry at room temperature and mounted using Entellan (Merck).

Quantitative analysis. The study area was the motor cortex, cut in coronal planes in rostro-caudal direction, using the knee of the corpus callosum as rostral reference and the anterior part of the hippocampus as caudal reference. For the quantitative study, we used rostral sections (at the level of the knee of the corpus callosum) and caudal sections (at dorsal hippocampal level) from five brains. From each of these two groups of sections, we selected three slides of the processed samples of each of the infected mice and their respective controls. We selected three sections per slide for each case. The qualitative observation and the quantitative analysis of MAP-2 immunoreactivity were performed using a Zeiss Axiophot microscope equipped for digitized image analysis using the QCapture Pro 6.0 tool and the software ImageJ. Densitometric measurements were performed by setting lower and upper threshold values to segment images into shades of black for positive immunoreaction, and white shades for background. The values were expressed in black shaded pixels; the higher the value the greater the intensity of immunoreaction (Table I).

\section{RESULTS}

The immunohistochemical technique for MAP-2 used in this work allowed us to delineate the microtubules in the apical dendrites of pyramidal neurons, from layers II to $\mathrm{V}$ of the cerebral cortex of mice, in the two areas of the motor cortex that were evaluated. It is worth noting the immunostaining (more diffuse) of layer I, corresponding to 
the distal dendrites of the pyramidal cells (Fig. 1A). MAP-2 immunoreactivity was qualitatively more intense in the samples of animals inoculated with either type of the rabies virus (street and fixed) by either route of inoculation (intracerebral or intramuscular). So evident was the effect of infection on MAP-2 immunoreactivity, that the somata
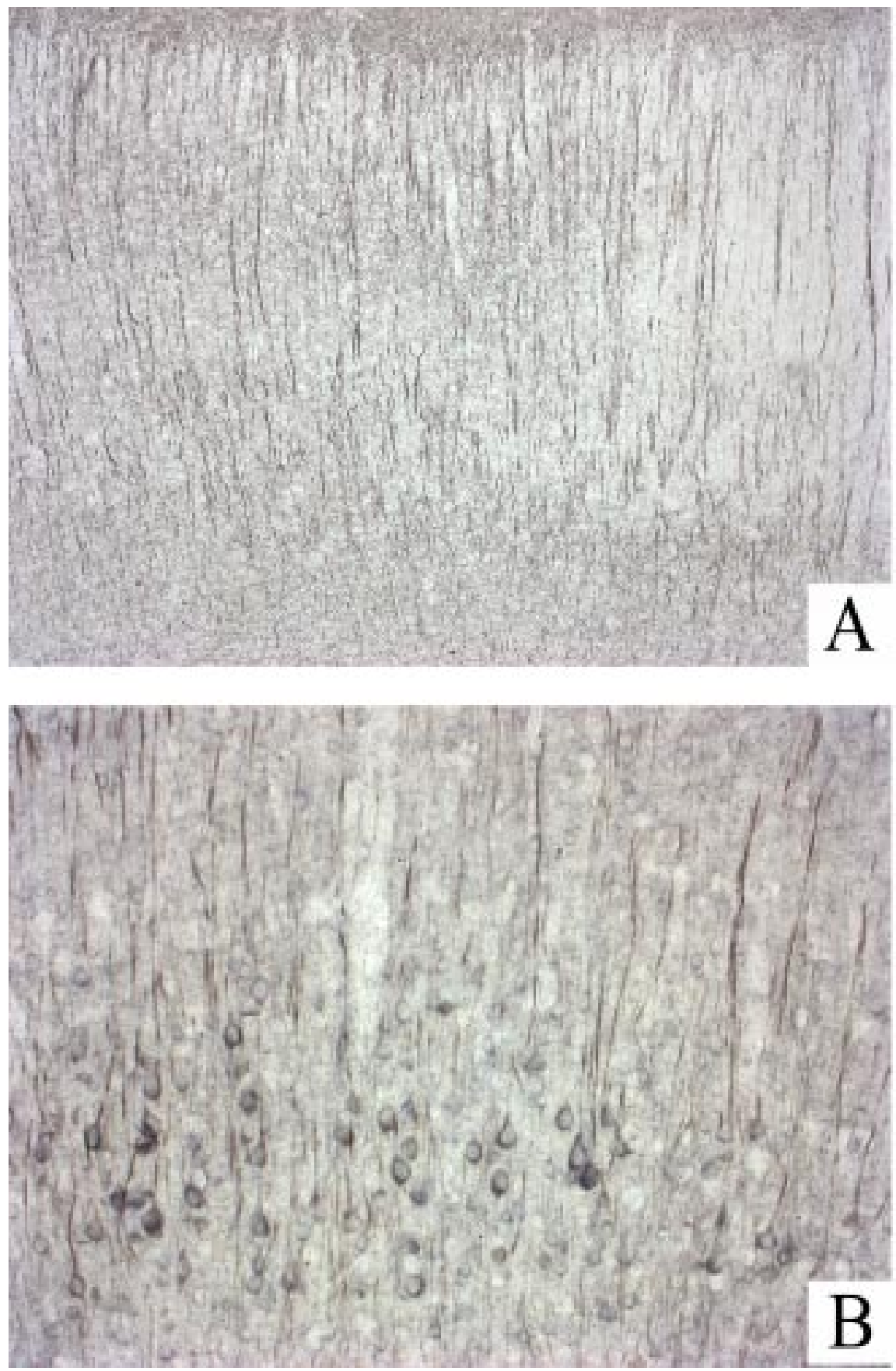

of the pyramidal neurons of layer $\mathrm{V}$ were visible in tissue sections from animals inoculated with rabies (Fig. 1B). The increased immunoreactivity in the samples from infected animals also manifested in a thickening of the microtubule bundles formed in the apical dendrites of pyramidal neurons (Figs. 1C and 1D). The qualitative observation was confirmed

Fig. 1. Images of MAP-2 Immunoreactivity in an anterior coronal plane of the motor cortex of a control mouse (A) and at a more posterior level of the motor cortex dorsal to the hippocampus, in an animal inoculated with the rabies virus (B). Besides the increased immunostaining in the infected sample, it is also evident the immunoreactivity in the somata of the pyramidal neurons in layer V. On side right is observed detail of MAP-2 immunoreactivity in apical dendrites of a control sample (C) and in a sample from an infected animal (D). It is worth noting the thickening of microtubules induced by the infection with rabies virus. DAB-Nickel. 10X (A), 20X (B), 80X (C and D). 
by a densitometric study that revealed a statistically significant difference in immunostaining results (Table I). Both the images in Figure 1 and the data presented in Table I correspond to samples of mice inoculated with street virus. The data obtained from samples of animals inoculated with fixed virus (not included) were very similar.

Table I. Densitometry data of MAP-2 immunoreactivity in the anterior and posterior motor areas of the cerebral cortex in control mice and in mice inoculated with street rabies virus. The value for each sample is the average from three histological preparations, in each of which three sections were measured. The increase in immunoreactivity in samples of infected animals was statistically significant in the samples from mice inoculated with rabies virus by either route (intracerebral or intramuscular). The values correspond to the number of black shaded pixels; the higher immunostaining the higher the value.

\begin{tabular}{|c|c|c|c|c|c|c|c|c|c|c|c|c|}
\hline \multirow{3}{*}{ Samples } & \multicolumn{6}{|c|}{ Intracerebral inoculation } & \multicolumn{6}{|c|}{ Intramuscular inoculation } \\
\hline & \multicolumn{3}{|c|}{ Anterior frontal cortex } & \multicolumn{3}{|c|}{ Posterior frontal cortex } & \multicolumn{3}{|c|}{ Anterior frontal cortex } & \multicolumn{3}{|c|}{ Posterior frontal cortex } \\
\hline & Controls & Infected & $\mathrm{P}$ value & Controls & Infected & $P$ value & Controls & Infected & $P$ value & Controls & Infected & $P$ value \\
\hline 1 & 35213 & 46297 & & 41052 & 45256 & & 67481 & 73604 & & 54671 & 70465 & \\
\hline 2 & 44241 & 48993 & & 37225 & 63281 & & 60955 & 75065 & & 61729 & 88951 & \\
\hline 3 & 46371 & 60063 & $0.0556^{*}$ & 20257 & 53554 & $0.0159 *$ & 51339 & 65794 & $0.0159 *$ & 62673 & 74064 & $0.0317 *$ \\
\hline 4 & 41772 & 75424 & & 42161 & 56815 & & 64352 & 77923 & & 73728 & 88235 & \\
\hline 5 & 63858 & 69538 & & 46746 & 58047 & & 64262 & 75530 & & 54165 & 73351 & \\
\hline
\end{tabular}

* Statistically significant.

\section{DISCUSSION}

Once the decisive role of the MAP-2 protein as an essential component of the cytoskeleton in the structure of the dendritic tree and in the maintenance of the stability of its three-dimensional morphology was established it did not take long to associate dendritic pathology with changes in the expression of MAP-2 in various neurological diseases (Johnson \& Jope). Although previous neurohistological studies have provided evidence of the effect of rabies infection on the dendritic structure (Li et al.; TorresFernández et al., 2007; Scott et al., 2008), little is known about the expression of MAP-2. In cultures of primary cortical neurons taken from mice and infected with a fixed virus strain, there was a total loss of MAP-2 immunoreactivity ( $\mathrm{Li}$ et $a l$.). Immunofluorescence was recently used with MAP-2 for delineating the morphology of hippocampal pyramidal neurons of mice inoculated with street virus and of their controls. The authors found no alterations in the structure and immunoreactivity of the somata and the apical dendrites as a result of infection, although the description was merely qualitative (Song et al.).

We found increased MAP-2 immunoreactivity in the cerebral cortex of mice inoculated with either type of rabies virus (fixed or street) by either route of inoculation (intracerebral or intramuscular). While the loss of MAP-2 expression has been associated with alterations in dendritic morphology in neuropathologies of different origin (Johnson \& Jope; Montgomery et al.; Kaufmann et al.; Broadbelt et $a l$.), other studies have reported dendritic pathology with increased expression of MAP-2. For example, in Rett syndrome (RS), there is loss of MAP-2 expression associated with dendritic pathology, while in Down Syndrome (DS) there is also dendritic pathology but with increase of MAP2 expression. Both cases involve phenomena common to the whole cerebral cortex, which has been confirmed by immunoblotting and immunohistochemistry, therefore conformational changes in the MAP-2 protein were not considered. In the case of DS, a redistribution of the MAP2 protein has been suggested, causing its accumulation in the shorter dendrites (Kaufmann et al.).

There also are reports of increased MAP-2 expression in the cerebral cortex of patients with early stage Alzheimer's disease (Mukateba-Ladinska et al., 2000) and in the pyramidal neurons of the cerebral cortex of patients with cortical dysplasia associated with cases of intractable epilepsy (Yamanouchi et al., 1996). Furthermore, an increased expression of MAP-2 has been induced in the dendrites of granule cells of the dentate gyrus of rats subjected to different experimental conditions (Koczyk, 1994; Schauwecker \& McNeill, 1996; Tang et al., 2014). In all cases, the authors propose a relationship between increased MAP-2 expression and loss of afferents (deafferentation) of granule cells, as well as a redistribution of MAP-2 from innervated areas of the hippocampus to denervated zones of the dentate gyrus.

In a study of mRNAs conducted on the brains of mice inoculated with CVS rabies virus, it was found that the expression of over $90 \%$ of the genes examined decreased markedly, but the expression of 39 of the genes (1.4\%) increased (Prosniak et al., 2001). Recently, a proteomic 
analysis of the frontal cortex of the brains of humans who died from rabies found 402 proteins differentially expressed, including 94 with increased expression. The expression of one of these proteins, the calcium/calmodulin-dependent protein kinase II (CAMKII), was validated by immunohistochemistry. Immunoreactivity was greater in pyramidal neurons of infected tissue (Venugopal et al., 2013). Two calcium-binding proteins of similar structure and function, calbindin (CB) and parvalbumin (PV), recognized as neuronal markers, exhibit differential immunoreactivity in the cerebral cortex and spinal cord of mice inoculated with rabies virus. While $C B$ decreases, $P V$ increases its expression. The increase of PV expression is a rare phenomenon in neuropathology (Torres-Fernández et al., 2004, 2005; Monroy-Gómez \& Torres-Fernández, 2013).

Kaufmann et al. highlight how difficult it is to explain an increase in dendritic proteins such as MAP-2, when a reduction in the size of the dendritic tree had been previously demonstrated, but there is no doubt that both the loss and the increased expression of MAP-2 may be related to dendritic pathology. Based on our knowledge of dendritic pathology in rabies (Torres-Fernández et al., 2007) and on the opinions of other authors mentioned above, we believe that the loss of MAP-2 precedes alterations in dendritic morphology, while the increase expression of the protein might occur after the dendritic damage. Thus, one could speculate that in rabies, the significant reduction of the dendritic tree of cortical pyramidal neurons and its deafferentation might induce a redistribution of MAP-2 so that it accumulates in the somata and the apical dendrites.

The increased expression of MAP-2 might also correspond to an effect of the virus on the synthesis of the protein due to a specific or non-specific activation of the corresponding gene (Prosniak et al.), or it might be a posttranslational effect (Venugopal et al.) on MAP-2, most likely due to changes in the phosphorylation of the protein. The phosphorylation of MAP-2 leads to the polymerization and increased rigidity of microtubules (Sánchez et al., 2000; Ikegami \& Setou, 2010). It is interesting to note that the mRNAs of MAP-2 and CAMKII have in common that they are located in greater proportion in the neuronal dendrites of adult brains (Kuhl \& Skehel, 1998), and CAMKII can phosphorylate MAP-2, increasing its ability to bind microtubules (Conde \& Cáceres). Interestingly the two proteins are overexpressed in neurons of brains infected with rabies.

Finally, MAP-2 is much more than a structural protein of neurons. During development and adulthood, it interacts with different biochemical systems, including neurotransmission systems that can affect the assembly of the cytoskeleton (Johnson \& Jope; Wilson \& Keith, 1998; Kaufmann et al.; Sánchez et al.). In the etiology of the pathogenesis of rabies, there is evidence of effect of the infection on neurotransmitters (Jackson \& Fu; Rengifo \& Torres-Fernández, 2007; Santamaría et al., 2010).

\section{ACKNOWLEDGMENT}

This work was funded by Instituto Nacional de Salud (INS, Colombia) and by Departamento Administrativo de Ciencia, Tecnología e Innovación (Colciencias) under the project with the code 210454531601 , contract $378 / 2011$. The first author (APH) was financed by Colciencias and INS under program 'Jovenes Investigadores e Innovadores'.

HURTADO, A. P.; RENGIFO, A. C. \& TORRES-FERNÁNDEZ, O. Aumento en la expresión inmunohistoquímica de MAP-2 en la corteza cerebral de ratones infectados con rabia. Int. J. Morphol., 33(2):465-470, 2015.

RESUMEN: La proteína asociada a microtúbulos MAP-2 es una parte integral del citoesqueleto y juega un papel importante en la morfogénesis neuronal. Esta proteína es un componente esencial del citoesqueleto de las dendritas, especialmente en el cerebro adulto, y su expresión puede ser alterada en condiciones experimentales o patológicas. El propósito de este estudio fue evaluar el efecto de la infección con el virus de la rabia sobre la inmunorreactividad de MAP-2 en la corteza cerebral de ratones. Ratones inoculados con el virus de la rabia fueron sacrificados cuando la enfermedad alcanzó su fase avanzada, junto con animales no infectados de la misma edad. Los cerebros se extrajeron después de que los animales fueron tratados con paraformaldehído mediante perfusión intracardiaca. En un vibrátomo se obtuvieron cortes coronales y estos se procesaron mediante inmunohistoquímica para revelar la presencia de la proteína MAP-2 en las neuronas de la zona motora de la corteza cerebral. Los ratones infectados con rabia mostraron un aumento en la inmunorreactividad de los somas y dendritas apicales en las neuronas piramidales de la corteza motora. Este es un resultado inesperado, ya que previamente se ha demostrado patología dendrítica en rabia, y algunos estudios sobre los trastornos neurológicos asocian las alteraciones dendríticas con pérdida de expresión de la proteína MAP-2. Por lo tanto, cualquiera que sea la alteración en la expresión de esta proteína, disminución o aumento, podría ser la causa de un desequilibrio bioquímico en la integridad y estabilidad del citoesqueleto neuronal.

PALABRAS CLAVE: MAP-2; Corteza cerebral; Neuronas piramidales; Virus de la rabia; Inmunohistoquímica. 


\section{REFERENCES}

Broadbelt, K.; Byne, W. \& Jones, L. B. Evidence for a decrease in basilar dendrites of pyramidal cells in schizophrenic medial prefrontal cortex. Schizophr. Res., 58(1):75-81, 2002.

Conde, C. \& Cáceres, A. Microtubule assembly, organization and dynamics in axons and dendrites. Nat. Rev. Neurosci., 10(5):319-32, 2009.

Ikegami, K. \& Setou, M. Unique post-translational modifications in specialized microtubule architecture. Cell Struct. Funct., 35(1):15-22, 2010.

Iwasaki, Y. \& Tobita, M. Pathology. In: Jackson, A. C. \& Wunner, H. W. (Eds.). Rabies. San Diego, Academic Press, 2002. pp.283-306.

Jackson, A. C. \& Fu, Z. F. Pathogenesis. In: Jackson, A. C. (Ed.). Rabies. Oxford, Academic Press, 2013. pp.299-349.

Johnson, G. V. \& Jope, R. S. The role of microtubule-associated protein 2 (MAP-2) in neuronal growth, plasticity, and degeneration. J. Neurosci. Res., 33(4):505-12, 1992.

Kaufmann, W. E.; MacDonald, S. M. \& Altamura, C. R. Dendritic cytoskeletal protein expression in mental retardation: an immunohistochemical study of the neocortex in Rett syndrome. Cereb. Cortex, 10(10):992-1004, 2000.

Koczyk, D. Differential response of microtubule-associated protein 2 (MAP2) in rat hippocampus after exposure to trimethyltin (TMT): an immunocytochemical study. Acta Neurobiol. Exp. (Wars.), 54(1):558, 1994.

Kuhl, D. \& Skehel, P. Dendritic localization of mRNAs. Curr. Opin. Neurobiol., 8(5):600-6, 1998.

Li, X. Q.; Sarmento, L. \& Fu, Z. F. Degeneration of neuronal processes after infection with pathogenic, but not attenuated, rabies viruses. $J$. Virol., 79(15):10063-8, 2005.

Monroy-Gómez, J. \& Torres-Fernández, O. Calbindin and parvalbumin distribution in spinal cord of normal and rabies-infected mice. Biomedica, 33(4):564-73, 2013.

Montgomery, M. M.; Dean, A. F.; Taffs, F.; Stott, E. J.; Lantos, P. L. \& Luthert, P. J. Progressive dendritic pathology in cynomolgus macaques infected with simian immunodeficiency virus. Neuropathol. Appl. Neurobiol., 25(1):11-9, 1999.

Mukaetova-Ladinska, E. B.; Garcia-Siera, F.; Hurt, J.; Gertz, H. J.; Xuereb, J. H.; Hills, R.; Brayne, C.; Huppert, F. A.; Paykel, E. S.; McGee, M.; Jakes, R.; Honer, W. G.; Harrington, C. R. \& Wischik, C. M. Staging of cytoskeletal and beta-amyloid changes in human isocortex reveals biphasic synaptic protein response during progression of Alzheimer's disease. Am. J. Pathol., 157(2):623-36, 2000.

Prosniak, M.; Hooper, D. C.; Dietzschold, B. \& Koprowski, H. Effect of rabies virus infection on gene expression in mouse brain. Proc. Natl. Acad. Sci. U. S. A., 98(5):2758-63, 2001.

Rengifo, A. C. \& Torres-Fernández, O. Decreased number neurons expressing GABA in the cerebral cortex of rabies-infected mice. Biomedica, 27(4):548-58, 2007.
Sánchez, C.; Díaz-Nido, J. \& Avila, J. Phosphorylation of microtubuleassociated protein 2 (MAP2) and its relevance for the regulation of the neuronal cytoskeleton function. Prog. Neurobiol., 61(2):133-68, 2000.

Santamaría, G.; Rengifo, A. C. \& Torres-Fernández, O. Expresión de glutamato en la corteza cerebral de ratones normales y ratones infectados con el virus de la rabia. Rev. Cient. Unincca, 15:67-81, 2010.

Schauwecker, P. E. \& McNeill, T. H. Dendritic remodeling of dentate granule cells following a combined entorhinal cortex/fimbria fornix lesion. Exp. Neurol., 141(1):145-53, 1996.

Scott, C. A.; Rossiter, J. P.; Andrew, R. D. \& Jackson, A. C. Structural abnormalities in neurons are sufficient to explain the clinical disease and fatal outcome of experimental rabies in yellow fluorescent proteinexpressing transgenic mice. J. Virol., 82(1):513-21, 2008.

Song, Y.; Hou, J.; Qiao, B.; Li, Y.; Xu, Y.; Duan, M.; Guan, Z.; Zhang, M. \& Sun, L. Street rabies virus causes dendritic injury and F-actin depolymerization in the hippocampus. J. Gen. Virol., 94(Pt. 2):27683, 2013.

Tang, L.; Lu, Y.; Zheng, W. \& Li, Y. Overexpression of MAP-2 via formation of microtubules plays an important role in the sprouting of mossy fibers in epileptic rats. J. Mol. Neurosci., 53(1):103-8, 2014.

Torres-Fernández, O.; Yepes, G. E. \& Gómez, J. E. Neuronal dentritic morphology alterations in the cerebral cortex of rabies-infected mice: a Golgi study. Biomedica, 27(4):605-13, 2007.

Torres-Fernández, O.; Yepes, G. E.; Gómez, J. E. \& Pimienta, H. J. Effect of rabies virus infection on the expression of parvalbumin, calbindin and calretinin in mouse cerebral cortex. Biomedica, 24(1):63-78, 2004.

Torres-Fernández, O.; Yepes, G. E.; Gómez, J. E. \& Pimienta, H. J. Calbindin distribution in cortical and subcortical brain structures of normal and rabies-infected mice. Int. J. Neurosci., 115(10):1375-82, 2005.

Venugopal, A. K.; Ghantasala, S. S.; Selvan, L. D.; Mahadevan, A.; Renuse, S.; Kumar, P.; Pawar, H.; Sahasrabhuddhe, N. A.; Suja, M. S.; Ramachandra, Y. L.; Prasad, T. S.; Madhusudhana, S. N.; Hc, H.; Chaerkady, R.; Satishchandra, P.; Pandey, A. \& Shankar, S. K. Quantitative proteomics for identifying biomarkers for Rabies. Clin. Proteomics, 10(1):3, 2013.

Wilson, M. T. \& Keith, C. H. Glutamate modulation of dendrite outgrowth: alterations in the distribution of dendritic microtubules. J. Neurosci. Res., 52(5):599-611, 1998.

Yamanouchi, H.; Zhang, W.; Jay, V. \& Becker, L. E. Enhanced expression of microtubule-associated protein 2 in large neurons of cortical dysplasia. Ann. Neurol., 39(1):57-61, 1996.

\section{Correspondence to:}

Orlando Torres-Fernández

Grupo de Morfología Celular

Instituto Nacional de Salud (INS)

Av. Calle 26 No. 51-20

Bogotá DC

COLOMBIA

Email: otorresf@ins.gov.co

Received: 18-09-2014

Accepted: 28-02-2015 